\title{
Cell Death of Spinal Motoneurons in the Chick Embryo following Deafferentation: Rescue Effects of Tissue Extracts, Soluble Proteins, and Neurotrophic Agents
}

\author{
Yin Qin-Wei, a James Johnson, David Prevette, and Ronald W. Oppenheim \\ Department of Neurobiology and Anatomy, and the Neuroscience Program, Bowman Gray School of Medicine, Wake \\ Forest University, Winston-Salem, North Carolina 27157
}

In the absence of descending spinal and supraspinal afferent inputs, neurons in the developing lumbar spinal cord of the chick embryo undergo regressive changes including cellular atrophy and degeneration between embryonic days 10 and 16. There are significant decreases in the number of motoneurons, interneurons, and sensory (dorsal root ganglion) neurons. Although there are several possible explanations for how afferents might regulate the maintenance of neuronal viability, we have focused attention on the putative role of neurotrophic agents in these events. Previous studies have shown that specific tissue extracts (e.g., muscle, brain), soluble proteins, growth factors, and trophic agents can promote the in vitro and in vivo survival of avian motoneurons during the period of natural cell death (embryonic days 610). Several of these agents were also effective following deafferentation. These included brain extract (BEX), muscle extract (MEX), conditioned medium from astrocyte cultures (ACM), as well as the following neurotrophic agents: nerve growth factor (NGF), brain-derived neurotrophic factor (BDNF), neurotrophin-3 (NT-3), S-100, insulin-like growth factor-I (IGF-I), ciliary neurotrophic factor (CNTF), plateletderived growth factor (PDGF), basic fibroblast growth factor (bFGF), and leukemia inhibitory factor (CDF/LIF). Both transforming growth factor- $\beta$ (TGF- $\beta$ ) and acidic fibroblast growth factor (aFGF) were ineffective. Although considerable more work is needed to determine which (and how) specific CNSderived trophic agents regulate motoneuron survival, the present results are consistent with the notion that neurotrophic agents released from or modulated by synaptic inputs to target neurons promote neuronal differentiation and survival in the CNS.

[Key words: development, spinal, motor neurons, neurotrophic, cell death, chick embryo, afferents]

During neuronal development large numbers of immature neurons are lost by a process of programmed or naturally occurring cell death (Oppenheim, 1991). In the spinal cord of the chick

\footnotetext{
Received Feb. 14, 1994; revised Apr. 18, 1994; accepted June 8, 1994.

This work was supported by NIH Grants NS 31380 and NS 20402, by a grant from the Amyotrophic Lateral Sclerosis Association (ALSA) and by Cephalon, Inc. and Amgen, Inc.

Correspondence and reprint requests should be addressed to Ronald W. Oppenheim at the above address.

aPresent address: Laboratory for Molecular Neuroscience, Mailman Research Center, McLean Hospital, 115 Mill Street, Belmont, MA 02178.

Copyright (C) 1994 Society for Neuroscience 0270-6474/94/147629-12\$05.00/0
}

embryo approximately one-half of all postmitotic motoneurons undergo cell death over a period of several days between $\mathrm{em}$ bryonic day (E) 6 and E12 (Hamburger, 1975; Chu-Wang and Oppenheim, 1978). Although previous studies have suggested that the skeletal muscle targets of motoneurons are the major, if not the sole, source of the signals that regulate the extent of cell loss, it is becoming increasingly clear for motoneurons, as well as for many other types of neurons, that there are very likely other sources of trophic signals besides those derived from targets (Cumningham, 1982; Oppenheim, 1991; Galli-Resta and Resta, 1992; Korsching, 1993). In addition to the possible role of trophic agents derived from or associated with afferent terminals, glia cells, the extracellular matrix, and from other nonneuronal cells (e.g., macrophages, connective tissue, etc.), signals mediated by neuronal activity are also receiving increasing attention as putative sources of trophic influence on developing neurons (Born and Rubel, 1988; Maderdrut et al., 1988; Collins et al., 1991; Rubel et al., 1991; Catsicas et al., 1992; Galli-Resta et al., 1993; Schmidt and Kater, 1993).

Following a previous observation showing that the removal of substantial amounts of descending afferent input to developing spinal motoneurons in the chick embryo results in enhanced cell death (Okado and Oppenheim, 1984), we have begun to explore the possible mechanisms for this induced cell loss. In this situation, deafferentation of lumbar motoneurons was achieved by the removal of two or three segments of thoracic neural tube on E2, thereby preventing the later projection of descending spinal and supraspinal axons to the lumbar region. Beginning on E10 and continuing until E15-16, 20-30\% of the surviving motoneurons undergo degeneration and death. The total cell loss between E6 and E15 is 70-80\% in deafferented embryos versus $50 \%$ for unoperated or sham-operated control embryos (with all of the loss, in this case, occurring between E6 and E11-12). Because local segmental and sensory afferents remain intact in this model, it has not been possible to determine whether complete deafferentation would result in the loss of virtually all lumbar motoneurons, as occurs following the total loss of motoneuron targets (Hamburger, 1958; Oppenheim et al., 1978). However, if one can extrapolate from the situation with avian ciliary ganglion (CG) neurons, this would seem a likely outcome. Total deafferentation of the $\mathrm{CG}$ results in as much induced cell death $(>90 \%)$ as is observed following target deletion (Furber et al., 1987).

Although there are several possible mechanisms that may account for the deafferentation-induced loss of spinal motoneurons, in the present article we focus mainly on the possible role 

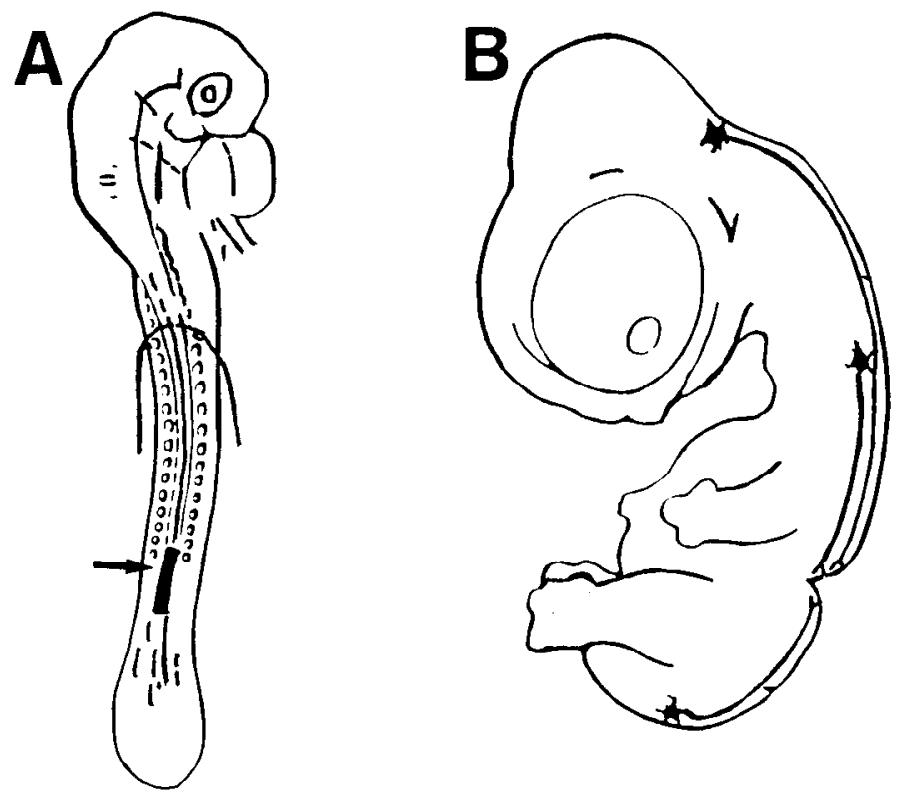

Figure 1. A spinal gap 2-4 somites long (arrow) was made in the presumptive thoracic neural tube on $\mathrm{E} 2(A)$. As shown in $B$, this serves to prevent the ingrowth of descending spinal and supraspinal afferent axons to the lumbar region (deafferentation).

of brain or spinal cord-derived neurotrophic signals that may be lost or perturbed following deafferentation. The rationale for this stems from observations made both in vitro and in vivo, indicating that soluble CNS-derived proteins can promote the survival of developing motoneurons during the period of naturally occurring cell death (Dohrmann et al., 1987; Yin et al., 1992; Johnson et al., 1994) and that they do so as effectively as proteins and tissue extracts derived from target muscle (Dohrmann et al., 1986, 1987; Oppenheim et al., 1988a, 1993; BlochGallego et al., 1991). Accordingly, our strategy has been to determine whether tissue extracts, soluble proteins, and purified growth factors that effectively rescue motoneurons from naturally occurring cell death in vitro and in vivo can also prevent the later induced cell loss following deafferentation. Together with the biochemical observations in the report by Johnson et al. (1994), these studies represent a beginning attempt to define the biological and biochemical properties of putative novel and known CNS-derived neurotrophic factors that serve as motoneuron survival agents during normal avian development.

\section{Materials and Methods}

Eggs. Fertilized eggs were obtained as a generous gift from Hubbard Farms, Statesville, NC, and were incubated in the laboratory at $37^{\circ} \mathrm{C}$ and $60 \%$ relative humidity until they reached the age required for experimentation.

Deafferentation. Prevention of the formation of descending spinal and supraspinal afferent inputs to the lumbar spinal cord was accomplished by removing three or four segments of the thoracic neural tube (somites 21-24) just rostral to the last thoracic segment (see Okado and Oppenheim, 1984). This created a "gap" in the neural tube that prevents axons from crossing in either direction (Fig. 1). Because the gap was created on E2 (stage 13-14; Hamburger and Hamilton, 1951), whereas the first descending afferents to the lumbar region do not appear until $2 \mathrm{~d}$ later (Oppenheim et al., 1988b), lumbar neurons develop in the absence of a significant portion of their normal descending afferent input. In all successful cases that were used for further analysis, a vertebral canal was formed in the operated (gap) region and the vasculature and other surrounding tissues appeared normal rostral and caudal to the gap (Fig. 2 ). Controls consisted of both unoperated and sham-operated embryos.
The sham operations involved removal and replacement of three or four segments of thoracic neuronal tube. Approximately one-third to one-half of controls were sham operated. There were no differences between sham versus unoperated controls, so the results have been pooled. Following surgery (or sham), the window in the shell was sealed with transparent adhesive tape and the eggs placed in an incubator where they remained unturned until embryos were killed for histology or until the initiation of treatment with tissue extracts or trophic agents.

Administration of trophic agents. Tissue extracts, conditioned medium, and trophic molecules were delivered (dropped) onto the highly vascularized chorio-allantoic (CAM) membrane through the window in the shell beginning on E9 and continuing daily until E15. Several previous studies have confirmed that this is an efficient and reliable method for the delivery of trophic agents, drugs, and neurotoxins to the avian embryo (Oppenheim et al., 1978, 1988a; Pittman and Oppenheim, 1979). Typically, the agents were administered in volumes of 50-100 $\mu$ l. Control embryos received 50-100 $\mu$ l of avian Ringers solution. Both aFGF and bFGF were always administered together with $25 \mu \mathrm{g}$ of heparin present in the injection solution. Tissue extracts and conditioned medium were prepared as described below. The purified or recombinant growth factors and trophic agents used here include: nerve growth factor (NGF), brain-derived neurotrophic factor (BDNF), neurotrophin-3 (NT3), $\mathrm{S}-100 \beta$, transforming growth factor- $\beta(\mathrm{TGF} \beta)$, ciliary neurotrophic factor (CNTF), insulin-like growth factor I (IGF-I), acidic and basic fibroblast growth factor (aFGF, bFGF), cholinergic differentiation factor/leukemia inhibitory factor (CDF/LIF) and platelet-derived growth factor (PDGF-AB). All of these agents were administered in doses of $5-10 \mu \mathrm{g} / \mathrm{d}$ from E9 to E15. Human recombinant BDNF, NT-3, PDGF, TGF- $\beta, b F G F$, and CDF/LIF were gifts from Amgen, Inc. Human recombinant CNTF was a gift from Synergen, Inc., and human recombinant IGF-I, a gift from Cephalon, Inc. Recombinant $\mathrm{S}-100$ was a gift from Linda Van Eldik. Purified murine NGF was provided by Eugene Johnson, Jr.

Preparation of brain and muscle extracts. Chick brain extract (BEX) was prepared from whole brains of E16 embryos, whereas muscle extracts $(\mathrm{MEX})$ were prepared from skinned and deboned hindlimb muscles of E16 embryos. Both brains and muscles were homogenized in a modified PBS solution containing $1 \mathrm{~mm}$ EDTA, EGTA, BEN, NEM, and $0.1 \mathrm{~mm}$ PMSF to minimize proteolysis. Homogenates were centrifuged $(1 \mathrm{hr}$ at $23,000 \times g)$ and the supernatant collected for $0-25 \%$, $25-75 \%$, and $100 \% \mathrm{AmSO}_{4}$ precipitation fractions. In each case, the $\mathrm{AmSO}_{4}$ was added dropwise, agitated for $2 \mathrm{hr}$, and precipitated protein recovered by centrifugation $(30 \mathrm{~min}$ at $15,000 \times \mathrm{g})$. Complete saturation is achieved by addition of $\mathrm{AmSO}_{4}$ to the $75 \%$ saturated supernatant, followed by equilibration for $18 \mathrm{hr}$ and centrifugation. The $0-25 \%, 25-$ $75 \%$, and $75-100 \%$ fractions are resuspended in $0.9 \% \mathrm{NaCl}$ to final volumes equal to one-fourth to one-half the original volume (protein concentration of $1.5-2.0 \mathrm{mg} / \mathrm{ml}$ ), dialyzed, and frozen. Crude BEX and the $\mathrm{AmSO}_{4}$ fractions were always dialyzed prior to use through a 1000 MWCO Spectrophor 1 membranes for 36-48 hr against two changes of $0.9 \% \mathrm{NaCl}$. After dialysis, samples were centrifuged for $15 \mathrm{~min}$ at 1000 $\times \mathrm{g}$ and any pellet that formed was discarded. Protein concentrations were determined using bicinchoninic acid (Smith et al., 1985). All the above procedures was carried out at $4^{\circ} \mathrm{C}$ and fractions were either used immediately or stored at $-70^{\circ} \mathrm{C}$ for no longer than $1-2$ weeks prior to use. Heat and trypsin treatment of crude BEX was as described (Oppenheim et al., 1988a, 1993) and was always carried out just prior to the use of BEX in an experiment.

Astrocyte-conditioned medium (CM). Astrocytes were purified from the cerebral cortices of neonatal mice according to the method of $\mathrm{Mc}$ Carthy and deVellis (1980). The brain tissue was dissected, the meninges removed, after which the tissue was minced and the cells dissociated. The dissociated cells were plated into $75 \mathrm{~cm}^{2}$ flasks on plastic (three to five cortices/flask) in medium containing $10 \%$ fetal calf serum. The first medium change is after $1 \mathrm{~d}$. After $1-2$ additional $\mathrm{d}$, ara-c $\left(5 \times 10^{-5} \mathrm{M}\right)$ and fluorodeoxyuridine $\left(10^{-5} \mathbf{M}\right)$ were added to inhibit fibroblast division and left for $2 \mathrm{~d}$. After this time, the medium only contains $10 \%$ fetal calf serum without mitotic inhibitors. Collection of the CM began when the cells were nearly confluent, which is approximately $6 \mathrm{~d}$ after the initial plating. The CM was passed through $0.8 \mu \mathrm{m}$ and $0.45 \mu \mathrm{m}$ filters, frozen $\left(-80^{\circ} \mathrm{C}\right)$ for $48 \mathrm{hr}$ and then lyophilized completely over $48 \mathrm{hr}$. The lyophilized material was later resuspended in distilled water, dialyzed against $0.9 \% \mathrm{NaCl}$ for $72 \mathrm{hr}$, and centrifuged and the supernatant was stored at $-80^{\circ} \mathrm{C}$. Prior to use for in vivo treatment of chick embryos, the CM was reconcentrated to $1-2 \mathrm{mg} / \mathrm{ml}$ protein in $0.9 \%$ 

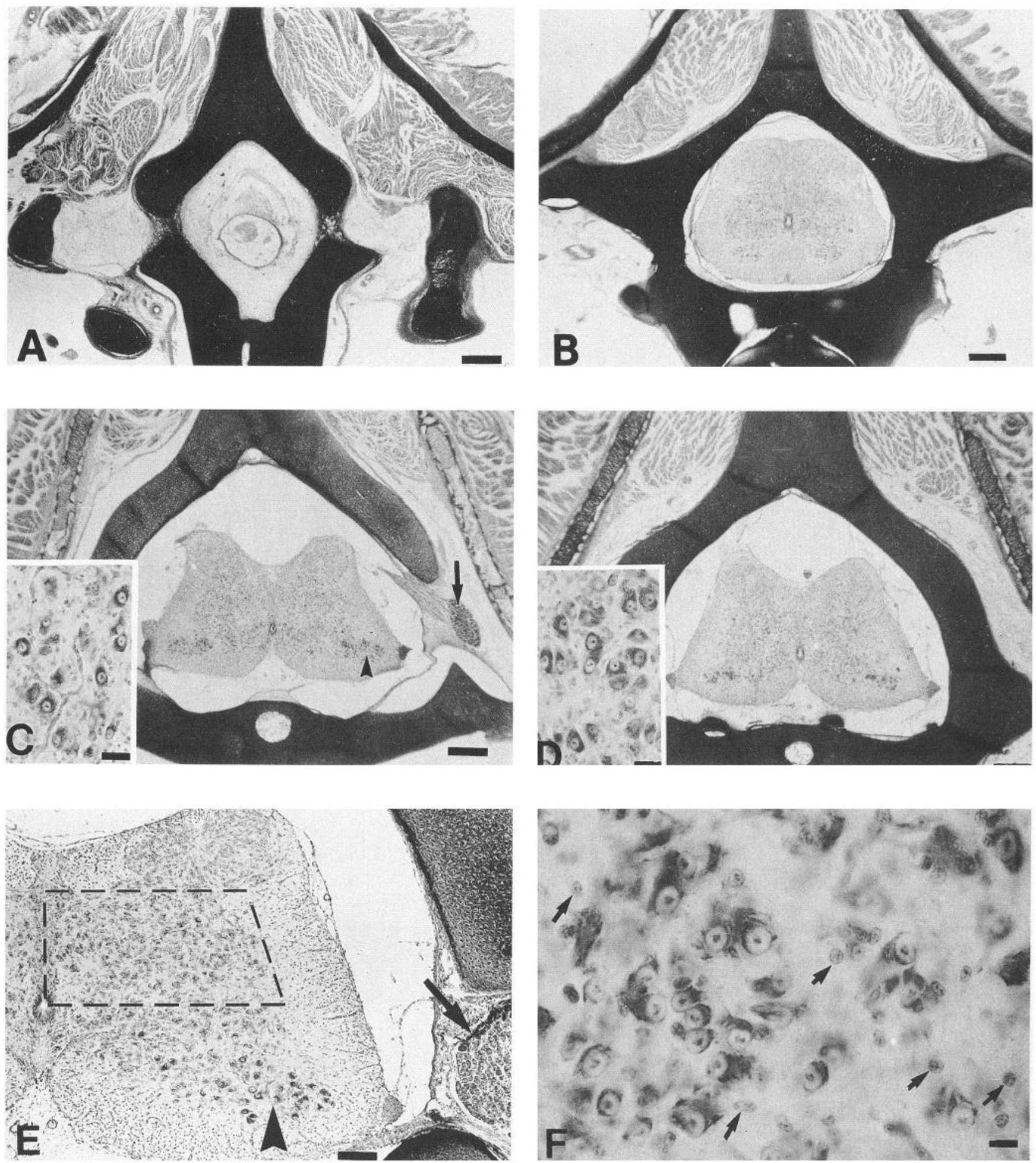

Figure 2. Photomicrographs of transverse sections of the spinal cord, and of spinal motoneurons and interneurons, in control and deafferented embryos on E16. $A$, A section through the thoracic gap region in which neural tissue is absent. $B$, A section through thoracic spinal cord just caudal to the gap. $C$ and $D$, Sections through the lumbar region (L3) of a control $(C)$ and deafferented $(D)$ embryo. Insets illustrate motoneurons in the lateral motor column. The arrow in $C$ (and $E$ ) indicates the dorsal root ganglion and the arrowheads in $C$ and $E$ the lateral motor column (ventral horn). $E$, Deafferented embryo indicating the region where interneurons were counted (dashed lines). $F$, Higher magnification of interneurons. Arrows in $F$ indicate some of the non-neuronal cells that were excluded from the counts of interneurons. Scale bars: $A-D, 250 \mu \mathrm{m} ; E, 100 \mu \mathrm{m} ; F$, $12 \mu \mathrm{m}$; insets, $22 \mu \mathrm{m}$. 


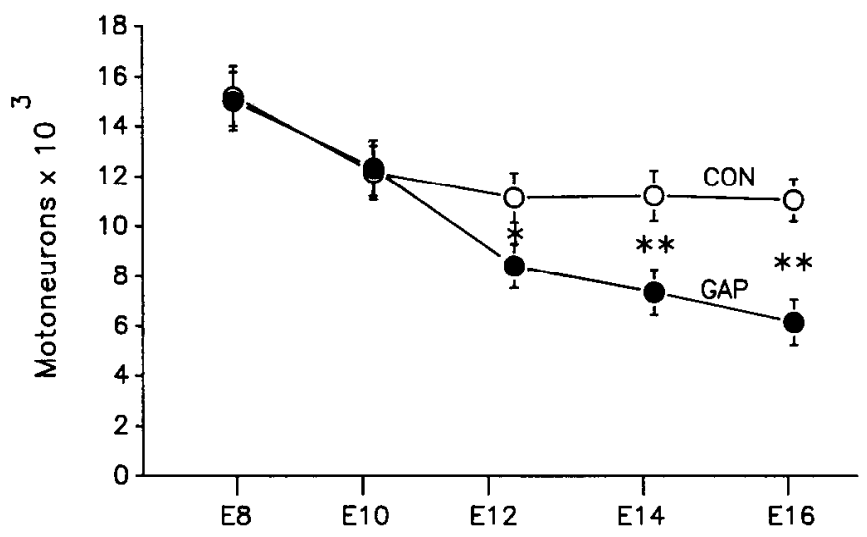

Figure 3. Motoneuron numbers (mean $\pm \mathrm{SD}$ ) in the lumbar spinal cord of control and deafferented embryos $(n=10-20$ for each data point). ${ }^{*}, P<0.01 ;{ }^{* *}, P<0.005$; control versus gap ( $t$ tests). Naturally occurring motoneuron death begins on $\mathrm{E} 6$, when there are approximately 22,000 motoneurons present, and continues until E12, although $90 \%$ of the cell loss occurs between E6 and E10.

saline and filter sterilized. Control embryos were treated with tissue culture medium containing $10 \%$ fetal calf serum.

Histology and morphometric analysis. Control and operated (gap) embryos were killed at various times between E8 and E16. The entire thoracolumbar spinal cord was dissected with vertebra and dorsal root ganglia (DRG) attached, immersion fixed in Carnoy's solution for 10$20 \mathrm{hr}$, and processed and embedded in paraffin. Serial transverse sections $(12 \mu \mathrm{m})$ were cut on a rotary microtome through the entire block, placed on slides, and stained with thionin. As shown in Figure 2, the success of the surgery could be easily ascertained from examination of sections through the thoracic gap region. Embryos that contained any neural tissue bridging the two sides of the gap were discarded.

Motoneurons in the lumbar lateral motor column (LMC, Fig. 2) were identified (Chu-Wang and Oppenheim, 1978) and counted in every 10th section using criteria that effectively exclude double counting of the same cell in adjacent sections (Oppenheim et al., 1989; Clark and Oppenheim, 1994). The values obtained were multiplied by 10 to give an estimate of total motoneuron numbers. Using the same criteria, interneurons in every 20 th section in the region of the gray matter delineated

Table 1. Motoneuron size (mean $\pm \mathrm{SD}$ ) and spinal cord length (mean \pm SD) on E16 in control and gap embryos and in gap embryos following treatment with exogenous agents

\begin{tabular}{|c|c|c|c|c|}
\hline & $\begin{array}{l}\text { Nuclear diam } \\
(\mu \mathrm{m})\end{array}$ & of $\mathrm{MN}$ & $\begin{array}{l}\text { Length of lumb } \\
(\mu \mathrm{m})\end{array}$ & \\
\hline & Mean $\pm \mathrm{SD}$ & $N$ & Mean \pm SD & $N$ \\
\hline Control & $12.8 \pm 0.16^{*}$ & $(50)$ & $6410 \pm 381^{* *}$ & (10) \\
\hline Gap & $11.5 \pm 0.10$ & $(50)$ & $6057 \pm 230$ & (11) \\
\hline $\mathrm{BEX}$ & $12.9 \pm 0.14^{*}$ & $(50)$ & $6400 \pm 414$ & (8) \\
\hline MEX & $13.0 \pm 0.13^{*}$ & (50) & $6387 \pm 490$ & (9) \\
\hline bFGF & $12.8 \pm 0.11^{*}$ & $(50)$ & $6400 \pm 336$ & (7) \\
\hline aFGF & $11.3 \pm 0.13$ & $(50)$ & $5916 \pm 478$ & (5) \\
\hline $\mathrm{S} 100$ & $12.8 \pm 0.12^{*}$ & $(50)$ & $6521 \pm 405^{* *}$ & (7) \\
\hline PDGF & $12.6 \pm 0.15^{*}$ & $(50)$ & $6180 \pm 155$ & (5) \\
\hline CNTF & $12.6 \pm 0.13^{*}$ & $(50)$ & $6460 \pm 393^{* *}$ & (7) \\
\hline BDNF & $12.8 \pm 0.14^{*}$ & $(50)$ & $6456 \pm 186^{* *}$ & (6) \\
\hline NT-3 & $12.7 \pm 0.13^{*}$ & $(50)$ & $6432 \pm 484^{* *}$ & (6) \\
\hline NGF & $12.1 \pm 0.17$ & $(50)$ & $6225 \pm 503$ & $(10)$ \\
\hline CDF/LIF & $12.1+0.18$ & $(50)$ & $6360+147$ & (6) \\
\hline IGF & $12.7 \pm 0.13^{*}$ & $(50)$ & $6456 \pm 157^{* *}$ & (6) \\
\hline TGF $-\beta$ & $11.9 \pm 0.14$ & $(50)$ & $6192 \pm 276$ & (6) \\
\hline
\end{tabular}

${ }^{*} p<0.01$ versus gap.

${ }^{* *} p<0.05$ verus gap.

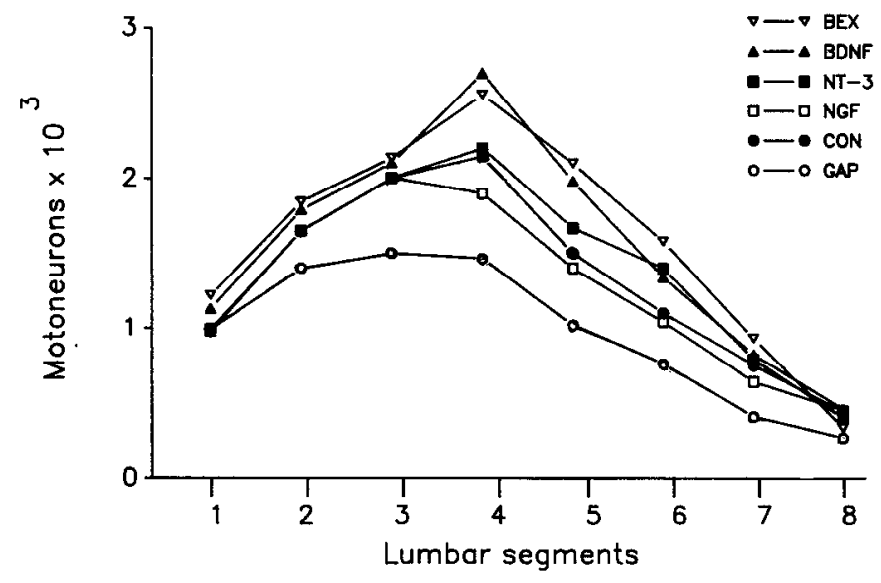

Figure 4. The distribution of motoneurons in each of the eight lumbar segments of control, gap, and treated embryos on E16. Segments were defined by adjacent dorsal root ganglia as described previously (Oppenheim et al., 1993).

in Figure 2 and DRG cells in the L3 ganglion were counted in every 5 th section. The values obtained for interneurons and DRG cells were multiplied by 20 and 5 , respectively, to generate estimates of total cell numbers. The histological slides were coded so that the person doing the cell counts was blinded as to whether a given embryo was a control or "factor"-treated animal. The region indicated in Figure 2 that was used to count interneurons excludes primarily laminae $1-4$ (dorsal horn) and laminae 8, 9, and a small part of 7, in the ventral region (Martin, 1979). The remaining area between the dashed lines comprises approximately $50 \%$ of the gray matter in both control and gap embryos on E16 (McKay and Oppenheim, 1991).

The length of the lumbar spinal cord was estimated by counting the total number of sections in which the LMC was detected ( $\mathrm{Ll}-\mathrm{L} 8$ ), and this number was then multiplied by the section thickness $(12 \mu \mathrm{m})$. Nuclear size (diameter) of motoneurons, which is roughly proportional to soma size (Oppenheim et al., 1982, 1992a), was measured as described (Oppenheim et al., 1988a).

\section{Results}

\section{Effects of deafferentation}

In agreement with our original report describing the effects of deafferentation on motoneuron survival (Okado and Oppenheim, 1984), we have confirmed that in this situation motoneuron numbers in the lumbar spinal cord initially die at the normal rate up to $\mathrm{E} 10$ at which time cell numbers are comparable in control and deafferented embryos (Fig. 3). However, between E10 and E16 there is a gradual increased loss of motoneurons such that by E16 deafferented embryos have 20-35\% fewer surviving cells. After E16, motoneuron numbers appear stabilized. In our earlier report, we also demonstrated that there were increased numbers of pyknotic (degenerating) motoneurons after E10 in deafferented embryos, indicating that the increased cell loss was owing to active cell death. This was also the case in the present study. On E13, there were virtually no pyknotic motoneurons observed in control embryos $(1.3 \pm 0.3$, $n=5$ ), whereas deafferented embryos exhibited an average of $43 \pm 11(n=5)$ pyknotic cells in lumbar segments L1-L8. The motoneuron loss that occurs following deafferentation involves virtually all regions (segments) of the lumbar cord (Fig. 4). Although we have also shown here that surviving deafferented motoneurons on E16 are slightly smaller than control motoneurons (Table 1), whether this slight (but statistically significant) difference is biologically meaningful is not clear. Histologically, motoneurons and interneurons in the deafferented cord appear healthy and fully differentiated and exhibit no obvious 


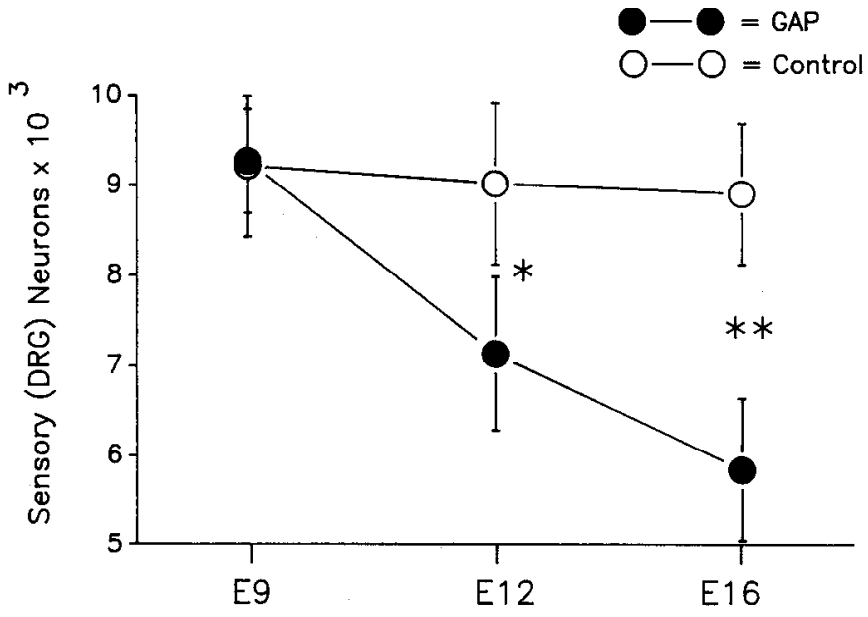

Figure 5. The number of sensory neurons (mean $\pm \mathrm{SD}$ ) in the L3 $\mathrm{DRG}$ on $\mathrm{E} 9, \mathrm{E} 12$, and E16 following deafferentation. ${ }^{*}, P<0.01$; **, $P<0.0005$ ( $t$ tests).

signs of atrophy or chromatolysis (Fig. 2). Again, however, these data on reduced cell size are consistent with the findings reported previously (Okado and Oppenheim, 1984).

Deafferentation of the lumbar spinal cord results in an overall reduction in the size of this region of the spinal cord. In our previous report, this was only an impression based on subjective criteria, whereas we have now confirmed this observation using lumbar spinal cord length as index of size. As shown in Table 1 , there was a small $(\sim 6 \%)$, but statistically significant, reduction in spinal cord size on E16 following deafferentation. A similar reduction in lumbar spinal cord size was found on E10 (data not shown). Despite the reduction in spinal cord and motoneuron size, the identification of the boundaries of the lateral motor column (ventral horn) and of motoneurons was unambiguous.

Following the creation of a gap in the thoracic neural tube, sensory neurons in the lumbar DRG with ascending projections would be prevented from reaching their more rostral targets. This situation could result in retrograde changes, including the death of DRG cells, which could, in turn, indirectly (e.g., transneuronally) influence the development and survival of neurons in the lumbar region. For this reason, we have examined cell numbers in one representative lumbar DRG (L3) on E9, E12, and E16 following deafferentation. Cell numbers in the deafferented embryos were normal on E9, but were reduced by $23 \%$ on E12 and by $35 \%$ on E16 (Fig. 5, Table 2). Preliminary observations indicate that there are similar reductions in DRG cells in other lumbar ganglia following deafferentation. The creation of a gap in the thoracic neural tube results in deafferentation of both motoneurons and interneurons in the lumbar cord, and also prevents rostrally projecting interneurons in the lumbar region from contacting their target neurons in the upper spinal cord and brain. Either or both events could directly affect the survival of interneurons and indirectly affect motoneuron survival. As shown in Figure 6, following deafferentation there is, in fact, a significant ( $25 \%$ ) reduction in the number of interneurons in the intermediate gray region of lumbar cord on E16.

Effects of treatment with tissue extracts and astrocyte-conditioned medium

In our initial experiments, in which deafferented embryos were treated daily from E9 to E15 with $200 \mu \mathrm{g}$ of protein of unfrac-
Table 2. Sensory neuron (L3 DRG) numbers (mean \pm SD) on E16 in control and gap embryos and in gap embryos following treatment with exogenous agents

\begin{tabular}{lcc} 
Treatment & Cell numbers & $N$ \\
\hline Control & $9207 \pm 979$ & 6 \\
Gap & $5840 \pm 926^{*}$ & 12 \\
BEX & $5997 \pm 1123^{*}$ & 9 \\
MEX & $6312 \pm 985^{*}$ & 5 \\
bFGF & $6071 \pm 970^{*}$ & 5 \\
aFGF & $6195 \pm 1122^{* *}$ & 5 \\
S100 & $8215 \pm 952$ & 5 \\
PDGF & $8028 \pm 1200$ & 4 \\
CNTF & $8364 \pm 649$ & 6 \\
BDNF & $10055 \pm 953$ & 5 \\
NT-3 & $9092 \pm 1130$ & 5 \\
NGF & $8239 \pm 876$ & 5 \\
CDF/LIF & $6110 \pm 1068^{*}$ & 5 \\
IGF-I & $6114 \pm 1209^{*}$ & 5 \\
TGF- $\beta$ & $6788 \pm 1041^{*}$ & 4 \\
\hline
\end{tabular}

${ }^{*} p<0.01$ versus control.

tionated (crude) BEX, we found that this treatment was sufficient to prevent the expected loss of motoneurons following deafferentation (Fig. 7). Furthermore, pretreatment of the crude BEX with heat or trypsin completely abolished this survival-promoting activity (Fig. 7). Biologically active crude BEX was able to rescue motoneurons following deafferentation in virtually all segments of the lumbar cord (Fig. 4). Because studies of the effect of BEX on naturally occurring motoneuron death in normal embryos between E6 and E10 indicated that a $25-75 \%$ $\mathrm{AmSO}_{4}$ fraction of $\mathrm{BEX}$ was most effective in rescuing cells (Johnson et al., 1994), we have also examined the effect of different $\mathrm{AmSO}_{4}$ fractions following dcafferentation. Neither the $0-25 \%$ nor the $75-100 \% \mathrm{AmSO}_{4} \mathrm{BEX}$ fractions were effective in this situation (Fig. 7). By contrast, the 25-75\% BEX fraction was as effective in preventing cell death following deafferentation as the crude, unfractionated BEX. In a beginning attempt to identify the cellular source of the survival activity in BEX, we have examined whether CM from astrocyte cultures (ACM) is effective in preventing cell death following deafferentation.

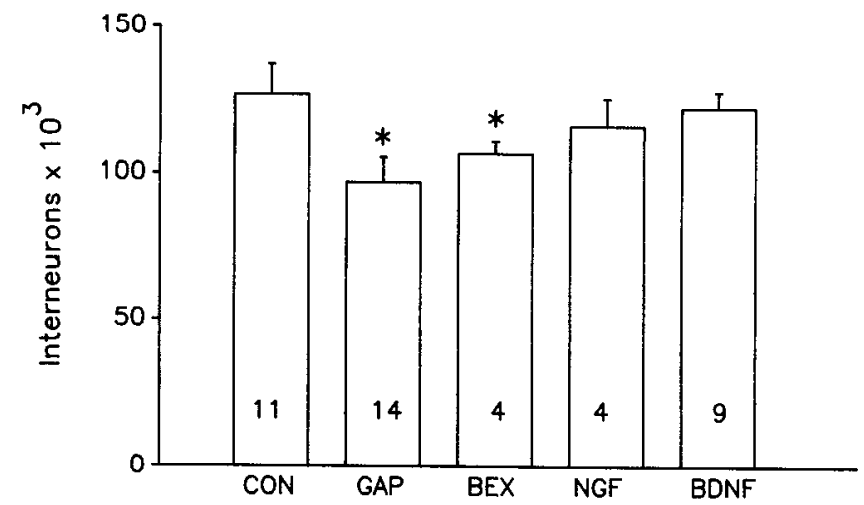

Figure 6. The number of lumbar interneurons (mean $\pm \mathrm{SD}$ ) on $\mathrm{E} 16$ in the region indicated in Figure 2 of control and deafferented $(G A P)$ embryos and of deafferented embryos treated with brain extract $(B E X)$, nerve growth factor $(N G F)$, or brain-derived neurotrophic factor $(B D N F)$. $*, P<0.01$ versus control ( $t$ tests). Both the $N G F$ and $B D N F$ groups are also significantly different from $\operatorname{Gap}(P<0.01)$. 


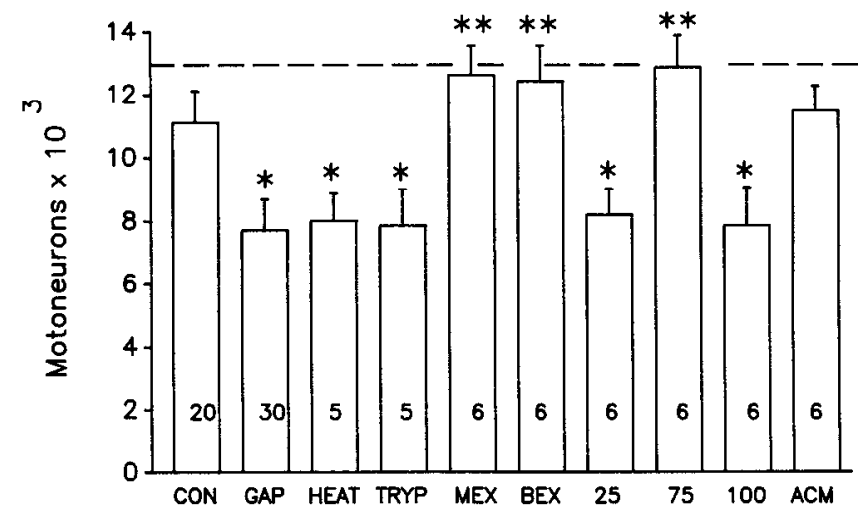

Figure 7. The number of lumbar motoneurons (mean \pm SD) on E16 in control and deafferented $(G A P)$ embryos and in deafferented embryos treated with crude brain extract $(B E X)$, heat- or trypsin-inactivated BEX, muscle extract $(M E X), \mathrm{AmSO}_{4}$ fractions of $\mathrm{BEX}(25 \%, 75 \%$, $100 \%$, see text), and astrocyte-conditioned medium $(A C M)$. The dashed line indicates the number of motoncurons present in control and gap embryos on E9, the age when treatment with exogenous agents began. As indicated in Figure 2, naturally occurring cell death continues until E12. *, $P<0.001$ versus control; ${ }^{* *}, P<0.01$ versus control $(t$ tests $)$.

As shown in Figure 7, ACM was, in fact, able to prevent the cell loss in this situation. Although we initially included MEX in this study as a negative control (not expecting that a putative muscle-derived trophic agent would prevent cell death following CNS deafferentation), in fact, as shown in Figure 7, MEX (25$75 \% \mathrm{AmSO}_{4}$ fraction) was as effective as BEX. Although BEX and MEX were also effective in preventing the reductions in both motoneuron and spinal cord size following deafferentation (Table 1), neither agent reversed the loss of DRG cells (Table 2). Furthermore, BEX was also ineffective in preventing the loss of interneurons in the lumbar cord (Fig. 6).

Because lumbar motoneurons in normal control embryos continue to undergo naturally occurring cell death between E9 and E12 (see Fig. 3), it was of interest to examine whether this later normal cell death could also be prevented by BEX, MEX, and

\begin{tabular}{|c|c|c|}
\hline Treatment & Cell numbers & $N$ \\
\hline Control & $10791 \pm 855$ & 18 \\
\hline MEX & $13016 \pm 917^{*}$ & 6 \\
\hline $\mathrm{BEX}$ & $13270 \pm 1020^{*}$ & 5 \\
\hline 25 & $10223 \pm 1115$ & 5 \\
\hline 75 & $13334 \pm 912^{*}$ & 7 \\
\hline 100 & $9931 \pm 1203$ & 5 \\
\hline $\mathrm{ACM}$ & $11501 \pm 616^{* *}$ & 5 \\
\hline bFGF & $10575 \pm 959$ & 5 \\
\hline $\mathbf{S} 100$ & $12413 \pm 970^{*}$ & 6 \\
\hline PDGF & $10309 \pm 861$ & 5 \\
\hline CNTF & $12871 \pm 890^{*}$ & 8 \\
\hline BDNF & $12511+767^{*}$ & 6 \\
\hline NT-3 & $10608 \pm 795$ & 5 \\
\hline $\mathrm{CDF} / \mathrm{LIF}$ & $10199 \pm 1003$ & 5 \\
\hline IGF-I & $12409 \pm 660^{*}$ & 7 \\
\hline TGF- $\beta$ & $10103 \pm 810$ & 5 \\
\hline
\end{tabular}

$* p<0.01$ versus control.

$* * p<0.05$ versus control.
Table 4. Motoneuron numbers (mean \pm SD) on E16 in control and gap embryos and in gap embyros treated with trophic agents

\begin{tabular}{|c|c|c|c|}
\hline Treatment & Cell numbers & $N$ & $\begin{array}{l}\% \\
\text { Differ- } \\
\text { ence } \\
\text { versus } \\
\text { gap }\end{array}$ \\
\hline Gap & $7715 \pm 977^{*}$ & 30 & 0 \\
\hline Control & $11108 \pm 1005$ & 20 & 30 \\
\hline $\mathrm{MEX}^{a}$ & $12591 \pm 1077$ & 6 & 39 \\
\hline $\mathrm{BEX}^{a}$ & $12413 \pm 1105$ & 6 & 38 \\
\hline BDNF & $12041 \pm 9926$ & 6 & 37 \\
\hline $\mathrm{S} 100$ & $11616 \pm 1000$ & 6 & 33 \\
\hline CNTF & $11511 \pm 9127$ & 7 & 33 \\
\hline PDGF & $11378 \pm 8076$ & 6 & 32 \\
\hline $\mathrm{NT}-3$ & $11216 \pm 8166$ & 6 & 31 \\
\hline CDF/LIF & $11050 \pm 9296$ & 6 & 30 \\
\hline bFGF & $10405 \pm 1223$ & 6 & 26 \\
\hline IGF-I & $10283 \pm 8057$ & 7 & 25 \\
\hline NGF & $10195 \pm 1007$ & 10 & 23 \\
\hline aFGF & $8129 \pm 1217^{*}$ & 5 & 5 \\
\hline $\mathrm{TGF}-\beta$ & $7810 \pm 956^{*}$ & 6 & 1 \\
\hline
\end{tabular}

${ }^{a}$ Data from Figure 7 for comparison.

${ }^{*} p<0.01$ versus control.

ACM. As shown in Table 3, treatment with BEX, MEX, and $\mathrm{ACM}$ from $\mathrm{E} 9$ to $\mathrm{E} 12$ prevented most of the normal motoneuron death during this period. Thus, treatment of deafferented embryos with these and other agents from E9 to E15 has the potential to prevent both natural and deafferentation-induced motoneuron death. This is the reason why in some cases trophic agent-treated deafferented embryos have significantly greater numbers of motoneurons on E16 than unoperated controls (e.g., see Fig. 7).

\section{Effects of ireatment with growth factors and trophic agents}

We have recently shown that a number of previously identified proteins with neurotrophic activity are able to rescue developing avian motoneurons from naturally occurring cell death when administered in vivo (Oppenheim et al., 1993), and several of these also promote the survival of purified populations of motoneurons in vitro (Arakawa et al., 1990; Martinou et al., 1990, 1992; Gouin et al., 1993; Henderson et al., 1993). Accordingly, it was of interest to determine whether any of these same agents are also effective in preventing motoneuron loss following deafferentation. Of the 11 agents tested, only two, TGF $\beta$ and aFGF, were ineffective (Table 4). The other agents tested varied somewhat in their ability to prevent cell death, with BDNF, CNTF, and $\mathrm{S} 100$ being the most effective, followed by NT-3, PDGF, and CDF/LIF (intermediate group), whereas IGF-1, NGF, and bFGF were the least effective (Table 4). However, it is important to point out that the differences in effectiveness between these various agents can be almost entirely accounted for by their differing abilities to prevent naturally occurring cell death between E9 and E12. For example, BDNF, S100, CNTF, IGF, MEX, and BEX effectively prevent motoneuron death during this period in unoperated embryos, whereas the other agents are either ineffective or less effective (Table 3). By contrast, all the agents tested (except for aFGF and TGF- $\beta$ ) were more or less comparable in their ability to prevent the specific cell loss in- 
duced by deafferentation (i.e., motoneuron numbers on E16 were similar to that of untreated control embryos). Although not all treatment groups were examined regarding the rostralcaudal distribution of rescued motoneurons, in those that were (NGF, BDNF, NT-3), it was apparent that treatment rescued deafferented motoneurons throughout the lumbar cord (Fig. 4).

With the exception of CDF/LIF, NGF, PDGF, aFGF, and TGF- $\beta$, all of the other agents that were examined for their effect on motoneuron and spinal cord size following deafferentation were found to prevent the reductions in either one or both of these two measures (Table 1).

As reported above, neither BEX nor MEX were able to prevent the loss of sensory neurons in the DRG following deafferentation. Similarly, bFGF, aFGF, TGF- $\beta$, IGF-1, and CDF/LIF were also ineffective on sensory neurons, whereas NGF, BDNF, NT-3, S-100, PDGF, and CNTF all promoted survival in the DKG following deafferentation, with BDNF and NT-3 being the most effective (Table 2). Although the survival of interneurons following dcafferentation has only been examined in the NGF- and BDNF-treated groups, it is of interest that both agents were able to rescue interneurons in this situation (Fig. 6).

\section{Discussion}

The removal of several segments of thoracic neural tube on E2 in the chick embryo creates a situation in which the lumbar region is isolated from descending influences from both spinal cord and supraspinal afferents. Axons from these rostral regions normally begin to innervate the lumbar cord between E4 and E5 (Singer et al., 1978; Oppenheim et al., 1988b; Shiga et al., 1991) with the major period of synaptogenesis being after E10 (Oppenheim et al., 1975). Although it is not possible to estimate quantitatively the precise extent to which lumbar motoneurons are deafferented by this procedure, it seems likely that a substantial amount of the normal input is derived from these rostral sources and that much of this input devclops during later stages, after E10. The fact that deafferentation does not affect motoneuron numbers until after E10 is consistent with this idea. Whereas motoneuron death up to E10 occurs at the normal rate in both control and deafferented embryos, between E10 and E16 deafferented embryos lose an additional 20-30\% of lumbar motoneurons. Because this loss is accompanied by an increase in the number of degenerating (pyknotic) motoneurons, we conclude that the reduction in cell number is a result of active motoneuron death. A similar loss of lumbar motoneurons has been reported following thoracic spinal transection in adult rats (Eidelberg et al., 1989) and there are many reports of increased cell death in other neuronal populations following deafferentation (for reviews, see Oppenheim, 1991; Rubel et al., 1991). Therefore, afferent regulation of neuronal survival is a widespread phenomenon occurring in different species and types of neurons.

Deafferentation also results in other changes in the lumbar cord, including reduced motoneuron and spinal cord size, as well as a reduction in the number of surviving sensory (DRG) neurons and interneurons. Deafferentation of neurons is known to result in cellular atrophy and other regressive changes (Globus, 1975; Deitch and Rubel, 1984). The reduction in spinal cord size can very likely be accounted for by a combination of factors, including reduced cell numbers (motoneurons, interneurons, and possibly glia) and the loss of descending fiber tracts. In any event, the small $(\sim 6 \%)$ reduction in spinal cord size cannot by itself account for (i.e., be the cause of the much greater reduction in numbers of motoneurons or interneurons. Additional evidence against this possibility comes from our observation that the spinal cord is already reduced in size on E10 prior to the increased loss of motoneurons in deafferented embryos. Additionally, the occurrence of increased numbers of dying cells on E13 following deafferentation also indicates that the loss of motoneurons is due to cell death and is not an artifact of reduced spinal cord or motoneuron size. Moreover, as noted previously (Pittman and Oppenheim, 1979; Okado and Oppenheim, 1984), motoneuron numbers can be increased, decreased, or unchanged in the face of decreased spinal cord and motoneuron size. Finally, it is also important to point out that the reduction in motoneurons cannot account for the loss of interneurons since even a virtually complete loss of motoneurons following limb bud removal does not alter the survival of spinal interneurons (McKay and Oppenheim, 1991).

We have previously found that spinal interneurons do not appear to undergo naturally occurring cell death. Rather, following their generation, interneuron numbers remain stable (McKay and Oppenheim, 1991). Therefore, it is unlikely that the loss of interneurons observed here reflects enhanced naturally occurring cell death. Instead, this loss appears to be a de novo event induced by the loss of afferents. It is interesting that this induced loss is restricted to subpopulations of interneurons. As reported previously (and as confirmed in the present study, data not shown), we failed to observe a reduction of interneurons in either the dorsal horn or in the ventral gray matter in proximity to the lateral motor column (McKay and Oppenheim, 1991). Rather, only interneurons in the gray matter in between these regions, which comprises about $50 \%$ of the total gray matter, were reduced in number following deafferentation. Perhaps the interneurons in this region are more severely deafferented by the surgery employed in creating a gap in the neural tube.

Bccausc some sensory neurons in the DRG, as well as some types of spinal interneurons, make direct synaptic contact with motoneurons, the reduction in survival of motoneurons in the present situation (gap) could be due either to reduced inputs from these local (lumbar) sources of input, or to the removal of descending (nonlumbar) inputs, or to some combination of these. Because treatment with some of the exogenous agents tested here (e.g., BEX) rescues deafferented motoneurons, but is without affect on interneuron survival, it seems unlikely that motoneuron death is secondary to the loss of interneurons. Similarly, because some of the agents tested (e.g., bFGF) prevent motoneuron death following deafferentation without affecting the survival of sensory neurons, it is also unlikely that the loss of motoneurons in this situation (in the absence of treatment) is secondary to the loss of inputs from sensory afferents. Additionally, in previous studies, treatment with NGF during the period of naturally occurring cell death rescued significant numbers of sensory neurons in the DRG, but was completely ineffective in promoting motoneuron survival (Oppenheim et al., 1982). Finally, because some of the effective agents examined by us (e.g., FGF, PDGF) are reported to be involved in myogenesis (Burgess and Macaig, 1989; Bowen-Pope et al., 1991), their mode of action in preventing cell death after deafferentation could be indirect via a direct effect on muscle differentiation. One argument against this is the fact that some of these agents can promote motoneuron survival in vitro in the complete absence of muscle cells (Dohrmann et al., 1986; Arakawa et al., 1990; Bloch-Gallego et al., 1991). In addition, we have previ- 
ously shown that MEX rescues motoneurons in vivo without affecting muscle development (Oppenheim et al., 1993).

$\Lambda \mathrm{n}$ alternative hypothesis is that the agents that prevent the death of motoneurons following deafferentation do so by acting directly on motoneurons. If this idea is correct, then there are at least two ways in which this direct effect on motoneurons may be mediated. Exogenous agents may either compensate for the loss of endogenous orthograde signals associated with descending afferents (e.g., Schecterson and Bothwell, 1992), or they may compensate for a loss of motoneuron access to target-derived neurotrophic agents, a loss that is somehow induced by the reduction in descending afferent inputs; that is, deafferented motoneurons may be at a disadvantage in gaining access to target-derived factors ( $\mathrm{Li}$ et al., 1992). Although at present, the data do not allow us to distinguish between these two possibilities, the fact that MEX is effective in rescuing motoneurons from deafferentation could be taken as supporting the "target" hypothesis. However, in this case we cannot exclude the possibility that MEX contains similar neurotrophic agents to those that are present in the CNS and which normally directly mediate survival via CNS afferents. For example, BDNF is expressed in both muscle and the CNS (Henderson et al., 1993; Koliatos et al., 1993; McKay et al., 1993). MEX may also contain factors different from those in the CNS, but which can, nonetheless, compensate for the loss of CNS-derived molecules.

A final possibility that we also cannot exclude is that the exogenous agents compensate for the loss of trophic support from non-neuronal (glial) cells, a loss that is somehow associated with deafferentation. Although some of the effective agents examined by us can promote the survival of purified populations of motoneurons in the absence of non-neuronal cells (Dohrmann et al., 1986, 1987; Arakawa et al., 1990; Gouin et al., 1993; Henderson et al., 1993), some of these agents (e.g., IGF, CNTF, NT-3) are also known to prevent the normal death of developing glial cells (Barres et al., 1992, 1993) and glial cells are known to be a rich source of neurotrophic agents (Barde et al., 1978; Lindsay, 1979; McCaffery et al., 1984; Eagleson et al., 1985; Manthrope et al., 1986; Bosch et al., 1988; Giulian et al., 1988; Eccleston et al., 1990; Acheson et al., 1991; Engele and Bohn, 1991; Matsuoka et al., 1991; Cunha and Vitkovic, 1992; Friedman et al., 1992). Therefore, following deafferentation some of the effective agents examined by us may either promote the survival of glial cells or stimulate the release of trophic agents from surviving glial cells.

It is of interest that some of the agents tested here that were effective in preventing the death of motoneurons following deafferentation (NGF, bFGF) have previously been shown to be ineffective in rescuing motoneurons from naturally occurring or programmed cell death (Oppenheim et al., 1982, 1988a, 1992a). One explanation for this difference is that deafferented neurons may express receptors for trophic factors that are not normally expressed or that are normally expressed only at low levels. For example, whereas developing motoneurons are known to express the low-affinity (P75) NGF receptor (Yan et al., 1988; Heuer et al., 1990), they are not thought to express the highaffinity biologically active $t r k \mathrm{~A}$ receptor (Henderson et al., 1993; Koliatsos et al., 1993; Yan et al., 1993) and, as predicted, NGF docs not prevent normal motoncuron cell death (Oppenheim et al., 1982, 1988a, 1992b). Nonetheless, as shown here, NGF is effective in rescuing deafferented motoneurons from cell death and it is also effective in preventing motoneuron death following peripheral axotomy in avian embryos and neonatal rats (Houe- nou et al., 1993; Yan et al., 1993). Although in these situations NGF may be either acting indirectly (e.g., via sensory afferents, but see above), or by activating other trk receptors that are expressed on motoneurons (Henderson et al., 1993; McKay et al., 1993; Tessarollo et al., 1993; Yan et al., 1993), it is also possible that following perturbation, trkA receptors are upregulated on avian motoneurons (e.g., Cheng and Mattson, 1991; Miwa et al., 1993), or on other neuronal or non-neuronal cells in the CNS that may then indirectly influence motoneuron survival by an NGF-induced release of other trophic agents. We are presently attempting to examine the expression of the mRNA for these receptors in the spinal cord following axotomy and deafferentation.

It is also conceivable that developing motoneurons normally change their trophic requirements, such that they depend upon different trophic agents before, during, and after the period of naturally occurring cell death (Barde et al., 1980; Eagleson and Bennett, 1986; Lindsay, 1988; Larmet et al., 1992; Wright et al., 1992; Buchman and Davies, 1993; Masu et al., 1993). For example, it is known that developing avian and mammalian motoneurons become gradually less dependent upon target-derived factors for their survival (Snider et al., 1992; Houenou et al., 1993) and that, in the case of avian embryos, this transition occurs at about the time that motoneurons become vulnerable to deafferentation. Thus, the normal transition in survival requirements from target dependency to afferent dependency may reflect the need for different trophic factors.

Because a wide variety of neurotrophic agents can also promote normal motoneuron survival both in vitro and in vivo (Arakawa et al., 1990; Gouin et al., 1993; Hughes et al., 1993a; Neff et al., 1993; Oppenheim et al., 1993), it is unlikely that the extensive responsiveness observed here is peculiar to the deafferentation situation. Furthermore, a similar widespread responsiveness to a variety of neurotrophic factors occurs following injury of other types of neurons (e.g., LaVail et al., 1992; Isacson, 1993). Thus, there is a growing recognition that developing motoneurons, as well as other types of neurons, may normally depend upon the combined action of multiple trophic factors (as well as on other types of signals) for optimum survival (Oppenheim, 1991; Hughes et al., 1993b; Korsching, 1993).

Although the survival of many types of developing neurons has been shown to depend upon signals associated with afferent inputs (Parks, 1979; Giordano and Cunningham, 1982; Davis et al., 1983; Okado and Oppenheim, 1984; Clarke, 1985; Friedman and Price, 1986; Furber et al., 1987; Linden and Pinon, 1987; Crewther et al., 1988; Hashisaki and Rubel, 1989; Sohal et al., 1992; Johnson and Bottjer, 1984), in only a few cases has the nature of these signals been examined in any detail. The synaptic activity of afferent inputs is one putative trophic signal that has been implicated in neuronal survival. The in vivo survival of sympathetic and parasympathetic neurons (Wright, 1981; Maderdrut et al., 1988), of neurons in the optic tectum and superior colliculus (Catsicas et al., 1992; Galli-Resta et al., 1993), and of neurons in the cochlear nuclei (Rubel et al., 1991) have all been shown to depend upon normal levels of synaptic transmission by afferents. In all of these cases, activity blockade results in reduced survival of postsynaptic neurons. Blockade of electrical activity in vitro also reduccs neuronal survival (Brenneman and Eiden, 1986; Lipton, 1986; Ramakers and Boer, 1991; Ramakers et al., 1991). By contrast, the chronic depolarization of neurons in vitro promotes survival in many cell types (Gallo et al., 1987; Collins et al., 1991; Ling et al., 1991; 


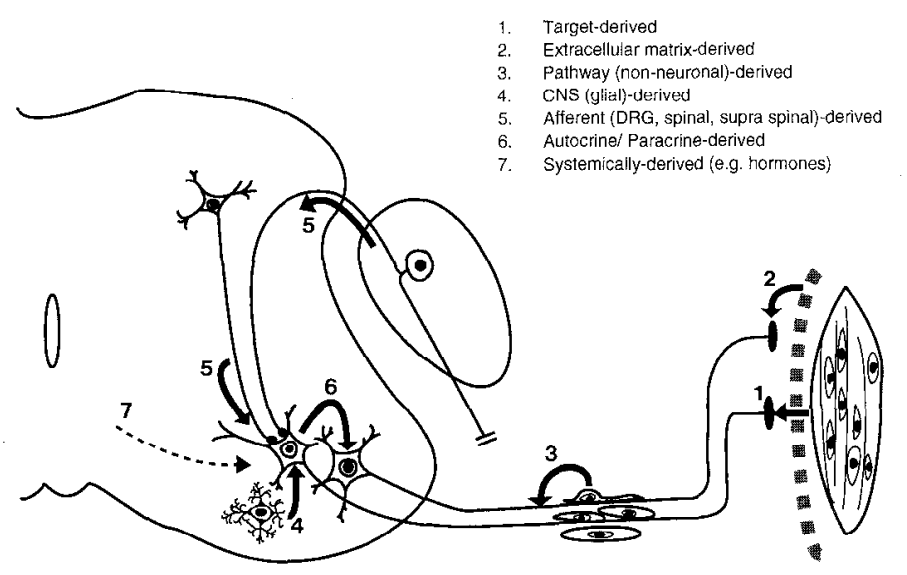

Figure 8. Schematic illustration of known and putative sources of trophic signals acting on spinal motoneurons. The dashed line adjacent to the muscle on the right represents extracellular matrix.

Franklin and Johnson, 1992). Depolarization-induced changes in neuronal survival appear to be mediated by the modulation of cytoplasmic calcium levels (Cheng and Mattson, 1991; Collins et al., 1991; Johnson et al., 1992). Therefore, it is possible that calcium regulates endogenous neurotrophic agents that would act in an autocrine or paracrine fashion (e.g., Lu et al., 1989; Elde et al., 1991; Ghosh et al., 1994). Another possibility is that activity may induce an upregulation of neurotrophic factor receptors in postsynaptic cells (Cohen-Cory et al., 1991, 1993; Isackson et al., 1991; Lu et al., 1991; Zafra et al., 1991; Birrin et al., 1992; Castrén et al., 1992; Gwag et al., 1993). It is also possible that depolarization-induced changes in cytoplasmic calcium may act by directly modulating the expression of genes involved in programmed cell death (e.g., Johnson and Deckwerth, 1993). One possibility that is clearly not supported by these data is that normal motoneuron death is a result of afferent excitotoxicity. If this were the case, one would expect decreased rather than increased death following deafferentation (see Fournier LeRay et al., 1993).

Although spinal motoneurons in the chick embryo are synaptically driven by afferent inputs during (and after) the period of naturally occurring cell death (Provine, 1972; Bekoff, 1976; Landmesser and O'Donovan, 1984; O'Donovan et al., 1992), in a previous study in the chick embryo, it was found that the loss of descending afferents did not alter the activity of lumbar motoneurons as measured by the amount of hindlimb motility (Okado and Oppenheim, 1984). Furthermore, direct perturbations of spinal cord electrical activity do not affect motoneuron survival in the chick (Okado and Oppenheim, 1984; Landmesser and Szente, 1987; Fournier Le Ray et al., 1993) or frog cmbryo (Olek and Edwards, 1980). Accordingly, although further studies are needed, it seems reasonable to argue that activity per se is not acting as a trophic signal in the afferent regulation of motoneuron survival.

Regardless of the specific mechanisms involved, our data provide support for the idea that afferent regulation of motoneuron survival during development may be mediated by neurotrophic agents. To this extent, our results are consistent with a modified version of the neurotrophic theory (e.g., Oppenheim, 1991; Thoenen, 1991; Korsching, 1993), one in which targets, afferents, and perhaps even non-neuronal cells are considered as normal sources of trophic support (Fig. 8). A more complete understanding of how afferents act to promote motoneuron survival will require the identification of the specific trophic molecules (and their receptors) that are involved (e.g., Johnson et al., 1994).

\section{References}

Acheson A, Barker PA, Alderson RF, Miller FD, Murphey RA (1991) Detection of brain-derived neurotrophic factor-like activity in fibroblasts and Schwann cells: inhibition by antibodies to NGF. Neuron 7:265-275.

Arakawa Y, Sendtner M, Thoenen H (1990) Survival effect of ciliary neurotrophic factor (CNTF) on chick embryonic motoneurons in culture: comparison with other neurotrophic factors and cytokines. J Neurosci 10:3507-3515.

Barde YA, Lindsay RM, Monard D, Thoenen H (1978) New factor released by cultured glioma cells supporting survival and growth of sensory neurons. Nature 274:818.

Barde YA, Edgar D, Thoenen H (1980) Sensory neurons in culture: changing requirements for survival factors during embryonic development. Proc Natl Acad Sci USA 77:1199-1203.

Barres BA, Hart IK, Coles HSR, Burne JF, Voyvodic IT, Richardson WD, Raff MC (1992) Cell death and control of cell survival in the oligodendrocyte lineage. Cell 70:31-46.

Barres BA, Schmid R, Sendtner M, Raff MC (1993) Multiple extracellular signals are required for long-term olidogendrocyte survival. Development 118:283-295.

Bekoff A (1976) Ontogeny of leg motor output in the chick embryo: a neural analysis. Brain Res 106:271-291.

Birrin SJ, Verdi JM, Anderson DJ (1992) Membrane depolarization induces p $140^{\text {rk }}$ and NGF responsiveness, but not p $75^{\text {LNGFR }}$, in MAH cells. Science 257:395-397.

Bloch-Gallego E, Huchet M, El M'Hamdi H, Xie FK, Tanaka H, Henderson CE (1991) Survival in vitro of motoneurons identified or purified by novel antibody-based methods is selectively enhanced by muscle-derived factors. Development 111:221-332.

Born DE, Rubel EW (1988) Afferent influences on brain stem auditory nuclei of the chicken: presynaptic action potentials regulate protein synthesis in nucleus magnocellularis neurons. J Neurosci 8:901-919.

Bosch EP, Assouline JG, Pantazis NJ, Lim R (1988) Schwann cell conditioned medium supports neurite outgrowth and survival of spinal cord neurons in culture. Muscle Nerve 11:324-330.

Bowen-Pope DF, Van Koppen A, Schatteman G (1991) Is PDGF really important? Testing the hypothesis. Trends Genetics 7:413-418.

Brenneman DE, Eiden LE (1986) Vasoactive intestinal peptide and electrical activity influence neuronal survival. Proc Natl Acad Sci USA 83:1159-1162.

Buchman VL, Davies AM (1993) Different neurotrophins are expressed and act in a developmental sequence to promote the survival of embryonic sensory neurons. Development 118:989-1001.

Burgess WH, Macaig T (1989) The heparin-binding (fibroblast) growth factor family of proteins. Annu Rev Biochem 58:575-606.

Castrén E, Zafra F, Thoenen H, Lindholm D (1992) Light regulates expression of brain-derived neurotrophic factor mRNA in rat visual cortex. Proc Natl Acad Sci USA 89:9444-9448.

Catsicas M, Péquignot Y, Clarke PGH (1992) Rapid onset of neuronal death induced by blockade of either axoplasmic transport or action potentials in afferent fibers during brain development. J Neurosci 12: $4642-4660$.

Cheng B, Mattson MP (1991) NGF and bFGF protect rat hippocampal and human cortical neurons against hypoglycemic damage by stabilizing calcium homeostasis. Neuron 7:1031-1041.

Chu-Wang IW, Oppenheim RW (1978) Cell death of motoneurons in the chick embryo spinal cord: light and electron microscopic study of naturally occurring and induced cell loss. J Comp Neurol 177:3358.

Clark PGH, Oppenheim RW (1994) Neuron death in vertebrate development: in vivo methods. In: Methods in cell biology: cell death (Schwartz L, Osborne B, eds), in press. New York: Academic.

Clarke PGH (1985) Neuronal death during development in the isthmo-optic nucleus of the chick: sustaining role of afferents from the tectum. J Comp Neurol 234:365-379.

Cohen-Cory S, Dreyfus CF, Black IB (1991) NGF and excitatory neurotransmitters regulate survival and morphogenesis of cultured cerebellar Purkinje cells. J Neurosci 11:462-471. 
Cohen-Cory S, Elliott RC, Dreyfus CF, Black IB (1993) Depolarizing influences increase low-affinity NGF receptor gene expression in cultured Purkinje neurons. Exp Neurol 119:165-175.

Collins F, Schmidt MF, Guthrie PB, Kater SB (1991) Sustained increase in intracellular calcium promotes neuronal survival. J Neurosci 11:2582-2587.

Crewther DP, Nelson JE, Crewther SG (1988) Afferent input for target survival in marsupial visual development. Neurosci Lett 86:147-154.

Cunha A, Vitkovic L (1992) Transforming growth factor-beta 1 (TGF$\beta 1)$ expression and regulation in rat cortical astrocytes. J Neuroimmunol 36:157-169.

Cunningham TJ (1982) Naturally occurring cell death and its regulation by developing neural pathways. Int Rev Cytol 74:163-185.

Davis MR, Constantine-Paton M, Schorr D (1983) Dorsal root ganglion removal in Rana pipiens tadpoles produces fewer motoneurons. Brain Res 265:283-288.

Deitch JS, Rubel EW (1984) Afferent influences on brain stem auditory nuclei of the chicken: time course and specificity of dendritic atrophy following deafferentation. J Comp Neurol 229:66-79.

Dohrmann U, Edgar D, Sendtner M, Thoenen H (1986) Muscle-derived factors that support survival and promote fiber outgrowth from embryonic chick spinal motor neurons in culture. Dev Biol 118:209221.

Dohrmann U, Edgar D, Thoenen H (1987) Distinct neurotrophic factors from skeletal muscle and the central nervous system interact synergistically to support the survival of cultured embryonic spinal motor neurons. Dev Biol 124:145-152.

Eccleston PA, Collarini EJ, Jessen KR, Mirsky R, Richardson WD (1990) Schwann cells secrete a PDGF-like factor: cvidence for an autocrine growth mechanism involving PDGF. Euro J Neurosci 2:985992.

Eidleberg E, Nguyen LH, Polich R, Walden JG (1989) Transsynaptic degeneration of motoneurones caudal to spinal cord lesions. Brain Res Bull 22:39-45.

Elde R, Cao Y, Cintra A, Brelje TC, Pelto-Huikko M, Junttila T, Fuxe K, Pettersson RF, Hökfelt T (1991) Prominent expression of acidic fibroblast growth factor in motor and sensory neurons. Neuron 7:349364.

Engele J, Bohn MC (1991) The neurotrophic effects of fibroblast growth factors on dopaminergic neurons in vitro are mediated by mesencephalic glia. J Neurosci 11:3070-3078.

Fournier Le Ray C, Prevette D, Oppenheim RW, Fontaine-Perus J (1993) Interactions between spinal cord stimulation and activity blockade in the regulation of synaptogenesis and motoneuron survival in the chick embryo. J Neurobiol 24:1142-1156.

Franklin JL, Johnson EM (1992) Suppression of programmed neuronal death by sustained elevation of cytoplasmic calcium. Trends Neurosci 15:501-508.

Friedman B, Price JL (1986) Age-dependent cell death in the olfactory cortex: lack of transneuronal degeneration in neonates. J Comp Neurol 246:20-31.

Friedman B, Scherer SS, Rudge JS, Helgren M, Morrisey D, McClain J, Wang D-Y, Wiegand SJ, Furth ME, Lindsay RM, Yip NY (1992) Regulation of ciliary neurotrophic factor expression in myelin-related Schwann cells in vivo. Neuron 9:295-305.

Furber S, Oppenheim RW, Prevette D (1987) Naturally occurring neuron death in the ciliary ganglion of the chick cmbryo following removal of preganglionic input: evidence for the role of afferents in ganglion cell survival. J Neurosci 7:1816-1832.

Galli-Resta L, Resta G (1992) A quantitative model for the regulation of naturally occurring death in the developing vertebrate nervous system. J Neurosci 12:4586-4594.

Galli-Resta L, Ensini M, Fusco E, Gravina A, Margheritti B (1993) Afferent spontaneous electrical activity promotes the survival of target cells in the developing retinotectal system of the rat. J Neurosci 13: 243-250.

Gallo V, Kungsbury A, Balázs R, Jorgensen OS (1987) The role of depolarization in the survival and differentiation of cerebellar granule cells in culture. $J$ Neurosci 7:2203-2213.

Giordano DL, Cunningham TJ (1982) Optic afferents, neuron maturation and neuron survival in the rat superior colliculus. Dev Brain Res 4:365-368.

Giulian D, Young DG, Woodward J, Brown DC, Lachman LB (1988) Interleukin-1 is an astroglial growth factor in the developing brain. $\mathbf{J}$ Neurosci 8:709-714.
Ghosh A, Carnahan J, Greenberg ME (1994) Requirement for BDNF in activity-dependent survival of cortical neurons. Science 263:16181622 .

Globus A (1975) Brain morphology as a function of presynaptic morphology and activity. In: Developmental neuropsychology of sensory deprivation (Riesen AH, ed), pp 9-91. New York: Academic.

Gouin A, Bloch-Gallego E, Tanaka H, Henderson CE (1993) Basic fibroblast growth factor and transforming growth factor-beta act synergistically to promote motoneuron survival in vitro. J Neurosci, in press.

Gwag BJ, Sessler FM, Waterhouse BD, Springer JE (1993) Regulation of nerve growth factor mRNA in the hippocampal formation: effects of $N$-methyl-D-aspartate receptor activation. Exp Neurol 121:160 171 .

Ilamburger V (1958) Regression versus peripheral control of differentiation in motor hypoplasia. Am J Anat 102:365-410.

Hamburger V (1975) Cell death in the development of the lateral motor column of the chick embryo. J Comp Neurol 160:535-546.

Hamburger V, Hamilton HL (1951) A series of normal stages in the development of the chick embryo. J Morphol 88:49-92.

Hashisaki GT, Rubel EW (1989) Effects of unilateral cochlea removal on anterioventral cochlear nucleus neurons in developing gerbils. J Comp Neurol 283:465-473.

Henderson CE, Camu W, Mettling C, Gouin A, Poulsen K, Karihaloo M, Rullamas J, Evans T, McMahan SB, Armanini MP, Berkemeier L, Phillips HS, Rosenthal A (1993) Neurotrophins promote motor neuron survival and are present in embryonic limb bud. Nature 363: $266-270$.

IIeuer JG, Fatemic-Nainie S, Wheeler EF, Bothwell M (1990) Structure and developmental expression of the chicken NGF receptor. Dev Biol 137:287-304.

Houenou LJ, Li L, Lo AC, Yan Q, Oppenheim RW (1993) Naturally occurring and axotomy-induced motoneuron death and its prevention by neurotrophic agents: a comparison between chick and mouse. Prog Brain Res, in press.

Hughes RA, Sendtner M, Goldfard M, Lindholm D, Thoenen H (1993a) Evidence that fibroblast growth factor 5 is a major muscle-derived survival factor for cultured spinal motoneurons. Neuron 10:369-377.

Hughes RA, Sendtner M, Thoenen H (1993b) Multiplicity versus redundancy of survival factors for rat motoneurons. Curr Biol, in press.

Isackson PJ, Huntsman MM, Murray KD, Gall CM (1991) BDNF mRNA expression is increased in adult rat forebrain after limbic seizures: temporal patterns of induction distinct from NGF. Neuron 6:937-948.

Isacson O (1993) On neuronal health. Trends Neurosci 16:306-308.

Johnson EM, Deckwerth TL (1993) Molecular mechanisms of developmental cell death. Annu Rev Neurosci 16:31-46.

Johnson EM, Taniuchi M, DiStefano PS (1988) Expression and possible function of nerve growth factor receptors on Schwann cells. Trends Neurosci 11:299-304.

Johnson EM, Koike T, Franklin J (1992) A "calcium set-point hypothesis" of neuronal dependence on neurotrophic factor. Exp Neurol 115:163-166.

Johnson F, Bottier SW (1994) Afferent influences on cell death and birth during development of a cortical nucleus necessary for learned vocal behavior in zebra finches. Development 120:13-24.

Johnson J, Qin-Wei Y, Prevette D, Oppenheim RW (1994) Biological and biochemical properties of brain-derived factors which rescue developing spinal motoneurons from cell death in the chick embryo. J Neurobiol, in press.

Koliatsos VE, Clatterbuck RE, Winslow JW, Cayouette MH, Price DL (1993) Evidence that brain-derived neurotrophic factor is a trophic factor for motoneurons. Neuron 10:359-367.

Korsching S (1993) The neurotrophic factor concept: a re-examination. J Neurosci 13:2739-2748.

Landmesser L, O'Donovan MJ (1984) Activation patterns of embryonic chick hindlimb muscles recorded in ovo and in an isolated spinal cord preparation. J Physiol (Lond) 347:189-204.

Landmesser I, Szente M (1986) Activation patterns of embryonic chick hind-limb muscles following blockade of activity and motoncuronc cell death. J Physiol (Lond) 380:157-174.

Larmet Y, Dolphin AC, Davies AM (1992) Intracellular calcium regulates the survival of early sensory neurons before they become dependent on neurotrophic factors. Neuron 9:563-574. 
LaVail MM, Unoki K, Yasumura D, Matthes MT, Yancopoulos GD, Steinberg RH (1992) Multiple growth factors, cytokines and neurotrophins rescue photoreceptors from the damaging effects of constant light. Proc Natl Acad Sci USA 89:11249-11253.

Li J-Y, Kling-Petersen A, Dahlstrom A (1992) Influence of spinal cord transection on the presence and axonal transport of CGRP-, chromogranin A-, VIP-, synapsin-1-, and synaptophysin-like immunoreactivities in rat motor nerve. J Neurobiol 23:1094-1110.

Linden R, Pinon LGP (1987) Dual control by targets and afferents of developmental neuronal death in the mammalian central nervous system: a study in the parabigeminal nucleus of the rat. J Comp Neurol 266:141-149.

Lindsay RM (1979) Adult rat brain astrocytes support survival of both NGF-dependent and NGF-insensitive neurons. Nature 282:80-82.

Lindsay RM (1988) Nerve growth factors (NGF, BDNF) enhance axonal regeneration, but are not required for survival of adult sensory neurons. J Neurosci 8:2394-2405.

Ling DSF, Petroski RE, Geller HM (1991) Both survival and development of spontaneously active rat hypothalamic neurons in dissociated culture are dependent on membrane depolarization. Dev Brain Res 59:99-103.

Lipton SA (1986) Blockade of electrical activity promotes the death of mammalian retinal ganglion cells in culture. Proc Natl Acad Sci USA 83:9774-9778.

Lu B, Buck CR, Dreyfus CF, Black IB (1989) Expression of NGF and NGF receptor mRNAs in the developing brain: evidence for local delivery and action of NGF. Exp Neurol 104:191-199.

Lu B, Yokoyama M, Dreyfus CF, Black IB (1991) Depolarizing stimuli regulate nerve growth factor gene expression in cultured hippocampal neurons. Proc Natl Acad Sci USA 88:6289-6292.

Maderdrut JL, Oppenheim RW, Prevette D (1988) Enhancement of naturally occurring cell death in the sympathetic and parasympathetic ganglia of the chicken embryo following blockade of ganglionic transmission. Brain Res 444:189-194.

Manthorpe M, Rudge JS, Varon S (1986) Astroglial cell contributions to neuronal survival and neuritic growth. In: Astrocytes, Vol 2 (Fedoroff S, Vernadakis A, eds), pp 315-376. New York: Academic.

Martin AH (1979) A cytoarchitectonic scheme for the spinal cord of the domestic fowl, Gallus gallus domesticus: lumbar region. Acta Morphol Neerl Scand 17:105-117.

Martinou JC, Thai LV, Valette A, Weber MJ (1990) Transforming growth factor $\beta 1$ is a potent survival factor for rat embryo motoneurons in culture. Dev Brain Res 52:175-181.

Martinou JC, Martinou I, Kato AC (1992) Cholinergic differentiation factor $(\mathrm{CDF} / \mathrm{LIF})$ promotes survival of isolated rat embryonic motoneurons in vitro. Neuron 8:737-744.

Masu Y, Wolf E, Holtmann B, Sendtner M, Brem G, Thoenen H (1993) Disruption of the CNTF gene results in motor neuron degeneration. Nature 365:27-32.

Matsuoka I, Meyer M, Thoenen H (1991) Cell-type specific regulation of nerve growth factor (NGF) synthesis in non-neuronal cells: comparison of Schwann cells with other cell types. J Neurosci 11:31653177 .

McCaffery CA, Raju TR, Bennett MR (1984) Effects of cultured astroglia on the survival of neonatal rat retinal ganglion cells in vitro. Dev Biol 104:441-448.

McCarthy KD, DeVellis J (1980) Preparation of separate astroglial and oligodendroglial cell cultures from rat cerebral tissue. J Cell Biol 85:890-902

McKay SE, Oppenheim RW (1991) Lack of evidence for cell death among avian spinal interneurons during normal development and following removal of targets and afferents. J Neurobiol 22:721-733.

McKay SE, Herzog K-H, Garner A, Tucker R, Oppenheim RW, Large $T$ (1993) Expression of BDNF and trk $\mathrm{B}$ during the development of the neuromuscular system in the chick embryo. Soc Neurosci Abstr 19: in press.

Merlio J-P, Ernfors P, Kokaia Z, Middlemas DS, Bengzon J, Kokaia M, Smith M-L, Sicsjo BK, Hunter T, Lindvall O, Persson H (1993) Increased reduction of the $t r k$ B protein tyrosine kinase receptor after brain insults. Neuron 10:151-164.

Miwa T, Miriizumi T, Sakashita H, Kimura Y, Donjo T, Furukawa M (1993) Transection of the olfactory nerves induces expression of nerve growth factor receptor in mouse olfactory epithelium. Neurosci Lett 155:96-98.

Neff NT, Prevette D, Houenou LJ, Lewis ME, Glicksman MA, Qin-
Wei Y, Oppenheim RW (1993) Insulin-like growth factors: putative muscle-derived trophic agents that promote motoneuron survival. J Neurobiol 24:1578-1588.

O'Donovan MJ, Sernagor E, Sholomenko G, Ho S, Antal M, Yee W (1992) Development of spinal motor networks in the chick embryo. J Exp Zool 261:261-273.

Okado N, Oppenheim RW (1984) Cell death of motoneurons in the chick embryo spinal cord. IX. The loss of motoneurons following removal of afferent inputs. J Neurosci 4:1639-1652.

Olek AJ, Edwards C (1980) Effect of anesthetic treatment on motor neuron death in Xenopus. Brain Res 191:483-488.

Oppenheim RW (1991) Cell death during development of the nervous system. Annu Rev Neurosci 14:453-501.

Oppenheim RW, Chu-Wang I-W, Foelix RF (1975) Some aspects of synaptogenesis in the spinal cord of the chick embryo: a quantitative electron microscopic study. J Comp Neurol 161:383-418.

Oppenheim RW, Chu-Wang I-W, Maderdrut JL (1978) Cell death of motoneurons in the chick embryo spinal cord: III. The differentiation of motoneurons prior to their induced degeneration following limb bud removal. J Comp Neurol 177:87-112.

Oppenheim RW, Maderdrut JL, Wells D (1982) Cell death of motoneurons in the chick embryo spinal cord. VI. Reduction of naturally occurring cell death in the thoraco-lumbar column of Terni by nerve growth factor. J Comp Neurol 210:174-189.

Oppenheim RW, Haverkamp LJ, Prevette D, McManaman JL, Appel SH (1988a) Reduction of naturally occurring motoneuron death in vivo by a target-derived neurotrophic factor. Science 240:919-922.

Oppenheim RW, Shneiderman A, Shimizu I, Yaginuma H (1988b) Onset and development of intersegmental projection in the chick embryo spinal cord. J Comp Neurol 275:159-180.

Oppenheim RW, Cole T, Prevette D (1989) Early regional variations in motoneuron numbers arise by differential proliferation in the chick embryo spinal cord. Dev Biol 133:468-474.

Oppenheim RW, Yin Q-W, Prevette D, Yan Q (1992a) Brain-derived neurotrophic factor rescues developing avian motoneurons from cell death. Nature 360:755-757.

Oppenheim RW, Prevette D, Fuller F (1992b) The lack of effect of basic and acidic fibroblast growth factors on the naturally occurring death of neurons in the chick embryo. J Neurosci 12:2726-2734.

Oppenheim RW, Prevette D, Haverkamp LJ, Houenou L, Qin-Wei Y, McManaman J (1993) Biological studies of a putative avian musclederived neurotrophic factor that prevents naturally occurring motoneuron death in vivo. J Neurobiol 24:1065-1079.

Parks TN (1979) Afferent influences on the development of the brain stem auditory nuclei of the chicken: otocyst ablation. J Comp Neurol 183:665-678.

Pittman R, Oppenheim RW (1979) Cell death of motoneurons in the chick embryo spinal cord. IV. Evidence that a functional neuromuscular interaction is involved in the regulation of naturally occurring cell death and the stabilization of synapses. J Comp Neurol 187:425466.

Provine RR (1972) Ontogeny of bioelectric activity in the spinal cord of the chick embryo and its behavioral implications. Brain Res 41: 365-378.

Ramakers GJA, Boer GJ (1991) Chronic suppression of bioelectric activity and cell survival in primary cultures of rat cerebral cortex: biochemical observations. Eur J Neurosci 3:154-161.

Ramakers GJA, Raadsheer FC, Corner MA, Ramackers FCS, van Leeuwen FW (1991) Development of neurons and glial cells in cerebral cortex cultured in the presence or absence of bioelectric activity. Eur J Neurosci 3:140-153.

Rubel EW, Falk PM, Canady KS, Steward O (1991) A cellular mechanism underlying activity-dependent transneuronal degeneration: rapid but reversible destruction of neuronal ribosomes. Brain Dysfunct 4:5574.

Schecterson LC, Bothwell M (1992) Novel roles for neurotrophins are suggested by BDNF and NT-3 mRNA expression in developing neurons. Neuron 9:449-463.

Schmidt ME, Kater SB (1993) Fibroblast growth factors, depolarization and substratum interact in a combinatorial way to promote neuronal survival. Dev Biol 158:228-237.

Shiga T, Künzi R, Oppenheim RW (1991) Axonal projections and synaptogenesis by supraspinal descending neurons in the spinal cord of the chick embryo. J Comp Neurol 305:83-95.

Singer HS, Skoff RP, Price DL (1978) The development of interseg- 
mental connections in embryonic spinal cord. Brain Res 141:197209.

Smith PK et al. (1985) Measurement of protein using bicinchoninic acid. Anal Biochem 150:76-85.

Sohal GS, Hirano S, Kumaresan K, Ali MM (1992) Influence of altered afferent input on the number of trochlear motor neurons during development. J Neurobiol 23:10-16.

Tessarollo L, Tsoulfas P, Martin-Zanca D, Gilbert DJ, Jenkins NA, Copeland NG, Parada LF (1993) trk C, a receptor for neurotrophin3 , is widely expressed in the developing nervous system and in nonneuronal tissues. Development 118:463-475.

Thoenen H (1991) The changing scenc of ncurotrophic factors. Trends Neurosci 14:165-170.

Wright EM, Vogel KS, Davies AM (1992) Neurotrophic factors promote the maturation of developing sensory neurons before they become dependent on these factors for survival. Neuron 9:139-150.

Wright L (1981) Cell survival in chick embryo ciliary ganglion is reduced by chronic ganglionic blockade. Dev Brain Res 1:283-286.
Yan Q, Snider WD, Pinzone JJ, Johnson EM (1988) Retrograde transport of nerve growth factor (NGF) in motoneurons of developing rats: assessment of potential neurotrophic effects. Neuron 1:335-343.

Yan Q, Elliott JL, Sun J, Matheson C, Zhang L, Mu X, Kex KL, Snider WD (1993) Influences of neurotrophins on mammalian motoneurons in vivo. J Neurobiol, in press.

Yin Q-W, Oppenheim RW, Johnson J, Prevette D (1992) Low molecular weight brain-derived proteins and neurotrophins can prevent motoneuron cell death induced by spinal deafferentation. Soc Neurosci Abstr 18:1297.

Zafra F, Castren E, Thoenen H, Lindholm D (1991) Interplay between glutamate and $\gamma$-aminobutyric acid transmitter systems in the physiological regulation of brain-derived neurotrophic factor and nerve growth factor synthesis in hippocampal neurons. Proc Natl Acad Sci USA 88:10037-10041. 